\title{
A Review of the Landscape of Targeted Immunomodulatory Therapies for Non-Infectious Uveitis
}

\author{
Srilakshmi M. Sharma · Dun Jack Fu · Kanmin Xue
}

Received: October 6, 2017 / Published online: November 30, 2017

(C) The Author(s) 2017. This article is an open access publication

\section{ABSTRACT}

Systemic immunomodulatory therapies are the principal means of managing non-infectious uveitis. This review aims to explore the current landscape of systemic uveitis treatments, including biologic therapies and the advent of biosimilar therapies.

Keywords: Biologics; Biosimilars; Interferon; Interleukins; Non-infectious uveitis; TNFa inhibitors

Enhanced Content To view enhanced content for this article, go to https://www.medengine.com/Redeem/ 86DCF06013C9D9AA.

Electronic supplementary material The online version of this article (https://doi.org/10.1007/s40123017-0115-5) contains supplementary material, which is available to authorized users.

S. M. Sharma $(\bowtie) \cdot$ D. J. Fu · K. Xue

Oxford University Hospitals NHS Foundation Trust, Oxford Eye Hospital, Oxford, UK

e-mail: Srilakshmi.sharma@ouh.nhs.uk

S. M. Sharma $\cdot$ K. Xue

Nuffield Laboratory of Ophthalmology, West Wing, John Radcliffe Hospital, University of Oxford,

Oxford, UK

\section{INTRODUCTION}

Uveitis is a group of diseases characterised by inflammation of the uveal tract and neighbouring structures. Inflammation affecting the posterior segment of the eye involving the choroid, vitreous and retina may lead to secondary damage of photoreceptors and, consequently, loss of vision [35]. Uveitis accounts for $10-15 \%$ of bilateral blindness in the developing world, making it the fourth most common cause of bilateral vision loss and the second most common treatable cause [70, 92]. The incidence of uveitis is estimated at 52.4 per 100,000 in the USA and aetiologies are grouped into infectious, non-infectious and a third, less populous group of 'masquerade' syndromes which includes malignancies [28]. Since uveitis typically affects the working age group (20-60 years of age), not only may quality of life be severely impacted but there may also be profound socioeconomic consequences for affected patients. This impact has stimulated the development of more effective treatment strategies for uveitis [4, 20, 94].

Non-infectious uveitis (NIU) arises from an inappropriate inflammatory response mounted by the immune system against antigens within the uvea and retina $[6,13,35]$. It may manifest as part of an autoimmune syndrome (e.g. Behçet's disease [BD], Vogt-Koyanagi-Harada [VKH] disease, and sarcoidosis) or is termed idiopathic when disease is isolated to the eyes [80]. Since 
this article focuses solely on non-infectious causes of uveitis, we will use the term uveitis synonymously with NIU.

The goal of therapy in uveitis is remission of active inflammation, preservation of visual function and prevention of tissue damage to the retina or optic nerve, all with the minimum of side-effects. Up until recently, corticosteroids have been the only globally licensed therapy for uveitis. Although successful in controlling inflammation, their long-term side-effects limit therapeutic application, requiring alternative or additional immunosuppressant or immune-modifying therapies.

Systemic therapies for uveitis may be broadly divided into conventional immunosuppressant agents and newer, targeted immunomodulatory therapies (IMTs). The first immunosuppressant to be used in humans with uveitis was the T-cell inhibitor, cyclosporine, whose efficacy was demonstrated in animal models and a clinical trial [71, 72]. Based upon this success, a range of steroid-sparing agents (in particular, tacrolimus, methotrexate and mycophenolate mofetil) traditionally used in other systemic immune-mediated diseases were adopted over the past 40 years. These have accrued evidence for efficacy through prospective and retrospective studies, but few placebo-controlled or comparative trials $[65,75,79,98]$. Although the antimetabolites (methotrexate, mycophenolate mofetil and azathioprine) and calcineurin-mediated T-cell inhibitors (cyclosporine and tacrolimus) are accepted as standard of care for NIU, these conventional immunosuppressants fail to adequately control uveitis in up to $40 \%$ of cases due to either poor efficacy or side-effects $[34,66,76]$. Moreover, they remain unlicensed by regulatory authorities for use in uveitis [66]. Therefore, there is a great need for more effective corticosteroid-sparing treatment for uveitis with an acceptable side-effect profile.

The discovery that the selective antagonism of $\mathrm{TNF} \alpha$ ameliorates joint inflammation in a mouse model of rheumatoid arthritis and its subsequent successful translation into humans using recombinant antibody technology has heralded the growth of therapies that modulate specific cytokine pathways $[17,60]$. These treatments target cytokine receptors, cytokines or immune cell surface markers in several inflammatory diseases and are known as biologic therapies because they are generated within living systems. Experimental animal models of uveitis have enabled the translation of TNF $\alpha$ biology to uveitis patients $[17,18]$. Interrupting or modulating specific cytokines of the immune system has generated newer, targeted therapies which aim to deliver predictable disease remission without compromising tolerability. In this manner, several potential future therapies are in development which target specific lymphocyte populations or key constituents of the inflammatory cascade.

The landscape of therapeutics for uveitis has undergone substantial change in recent years, partly due to the revolution in biologic therapies but also due to interest in local therapies for treatment of intraocular inflammation $[43,56]$. We will present a brief overview of the evolution of uveitis therapies through the lens of key clinical trials, aimed at readers unfamiliar with uveitis therapies and for practitioners requiring an update on therapeutic modalities under current or recent investigation. The focus will be principally on systemic uveitis therapies from 2011 onwards based on a review of published literature and two clinical trial registries (clinicaltrialsregister.eu and clinicaltrials.gov). We will also consider the role of biosimilar drugs since the cost of treatment is an important contributor to the accessibility of therapies to patients.

\section{METHODS}

A literature review was conducted through comprehensive searches of five databases (EMBASE via Ovid, MEDLINE, ClinicalTrials.gov, EU Clinical Trials Register, and ISRCTN Registry) from January 2011 onwards. Search strategy and inclusion criteria are detailed in Supplementary Materials. A summary of clinical trials reported in this article are located in Table 1. Unreported clinical trials are summarized in Supplementary Materials. This article is based on previously conducted studies and does not involve any new studies of human or animal subjects performed by any of the authors. 


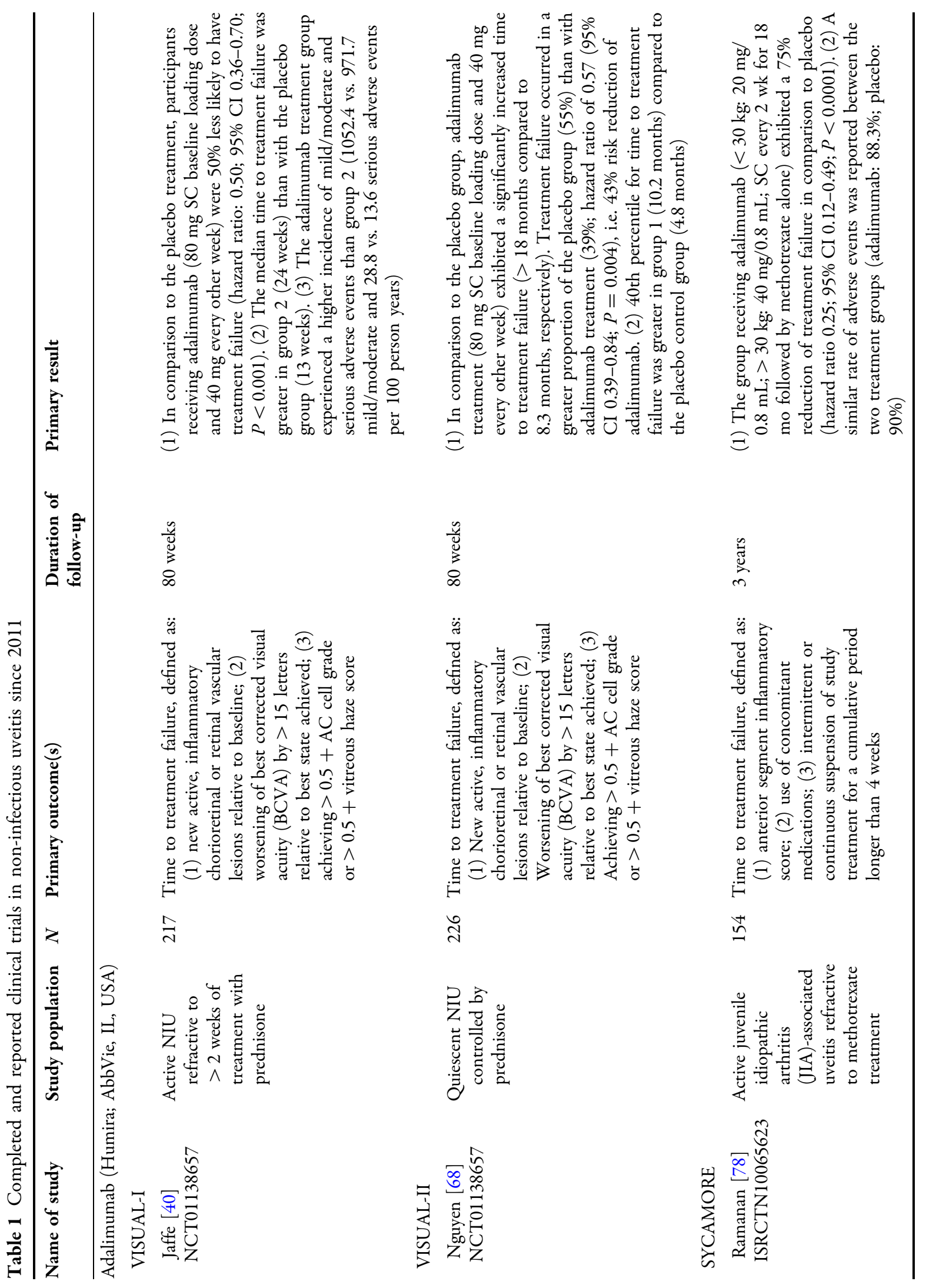



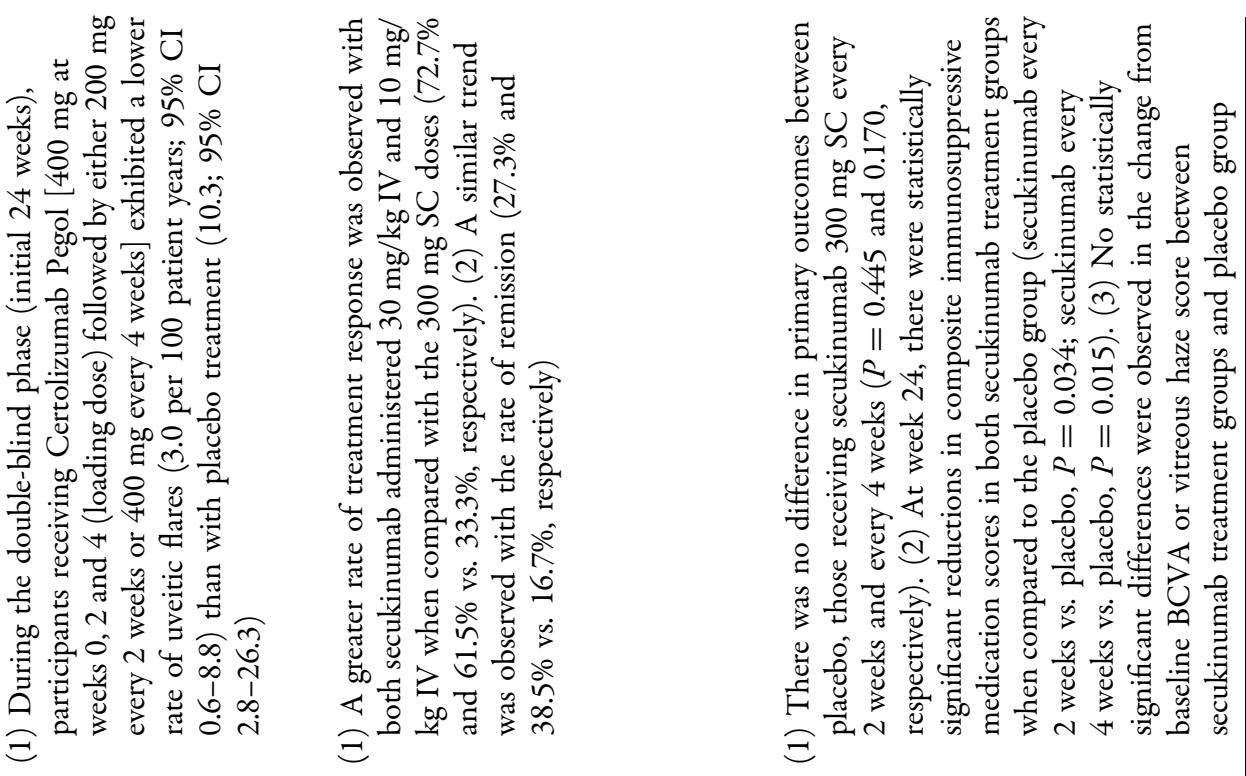

$\frac{\tilde{y}}{3}$

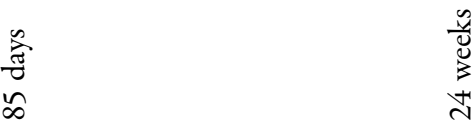

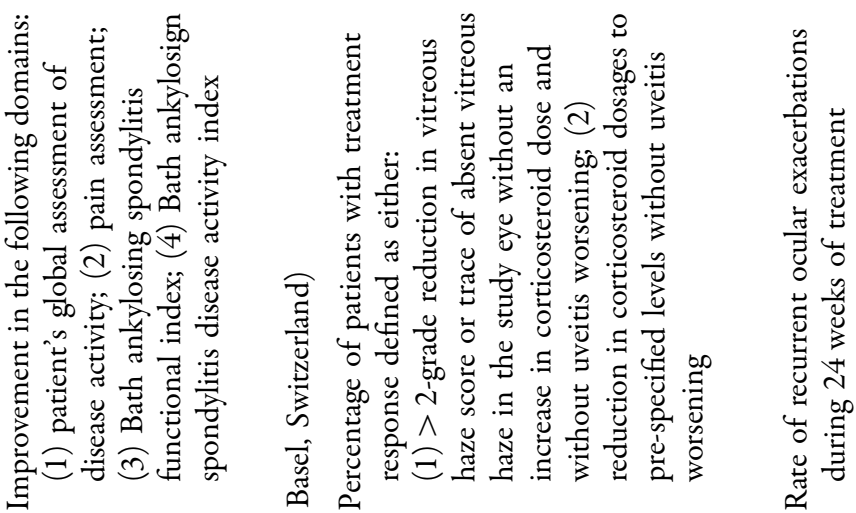

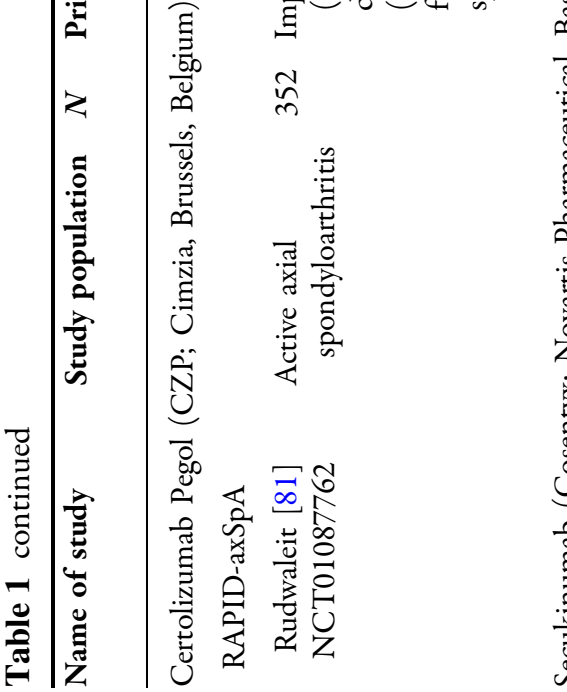

m

$\stackrel{\infty}{=}$

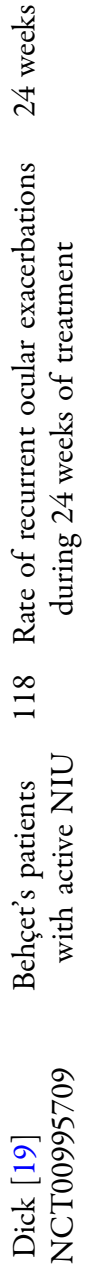
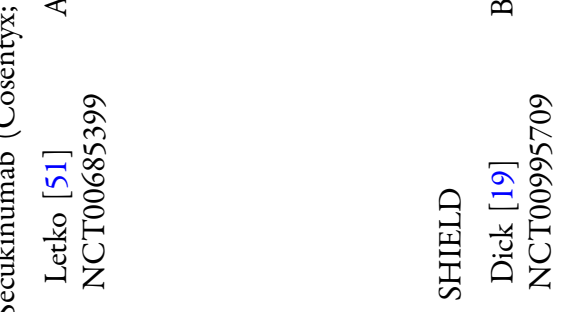


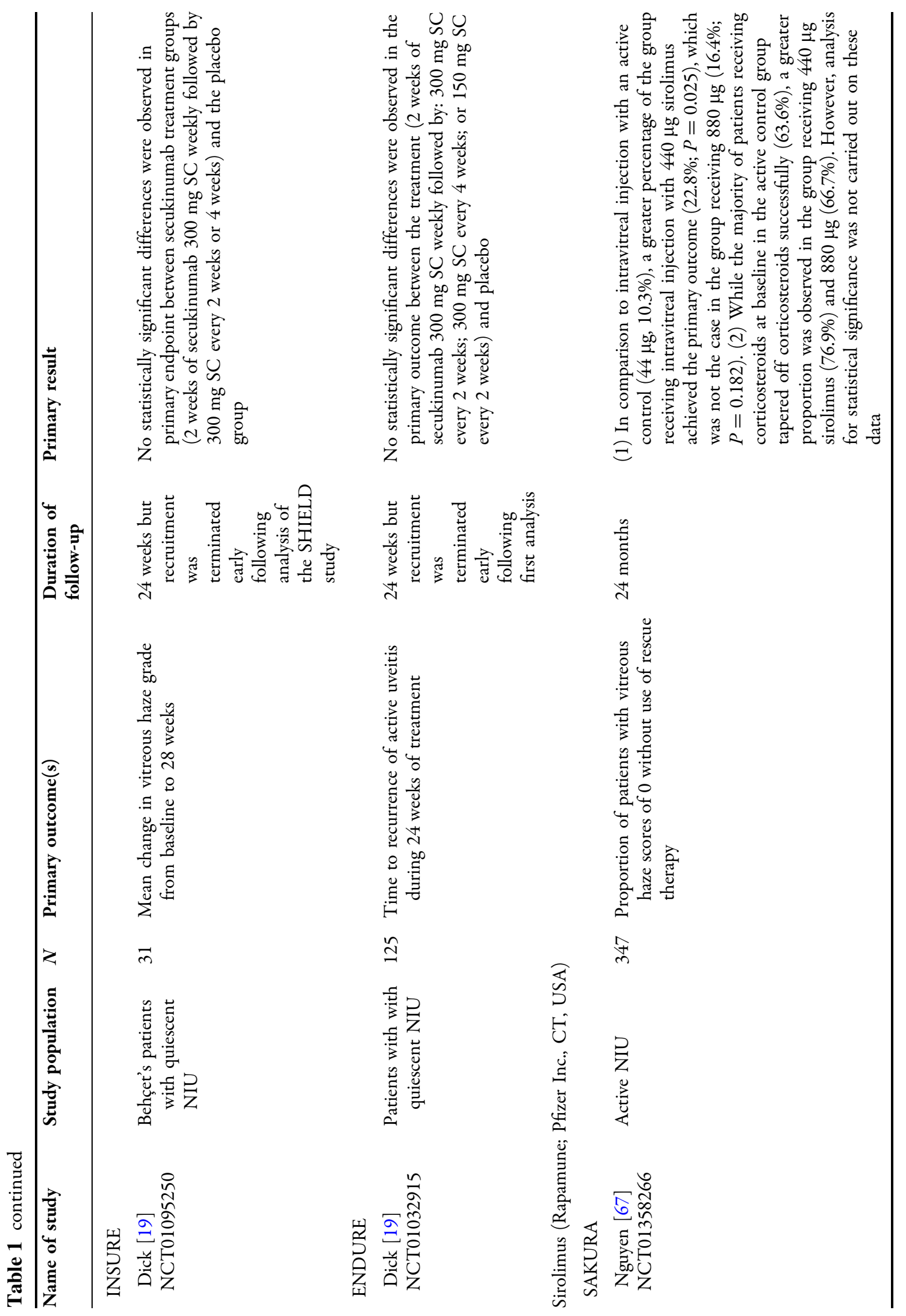




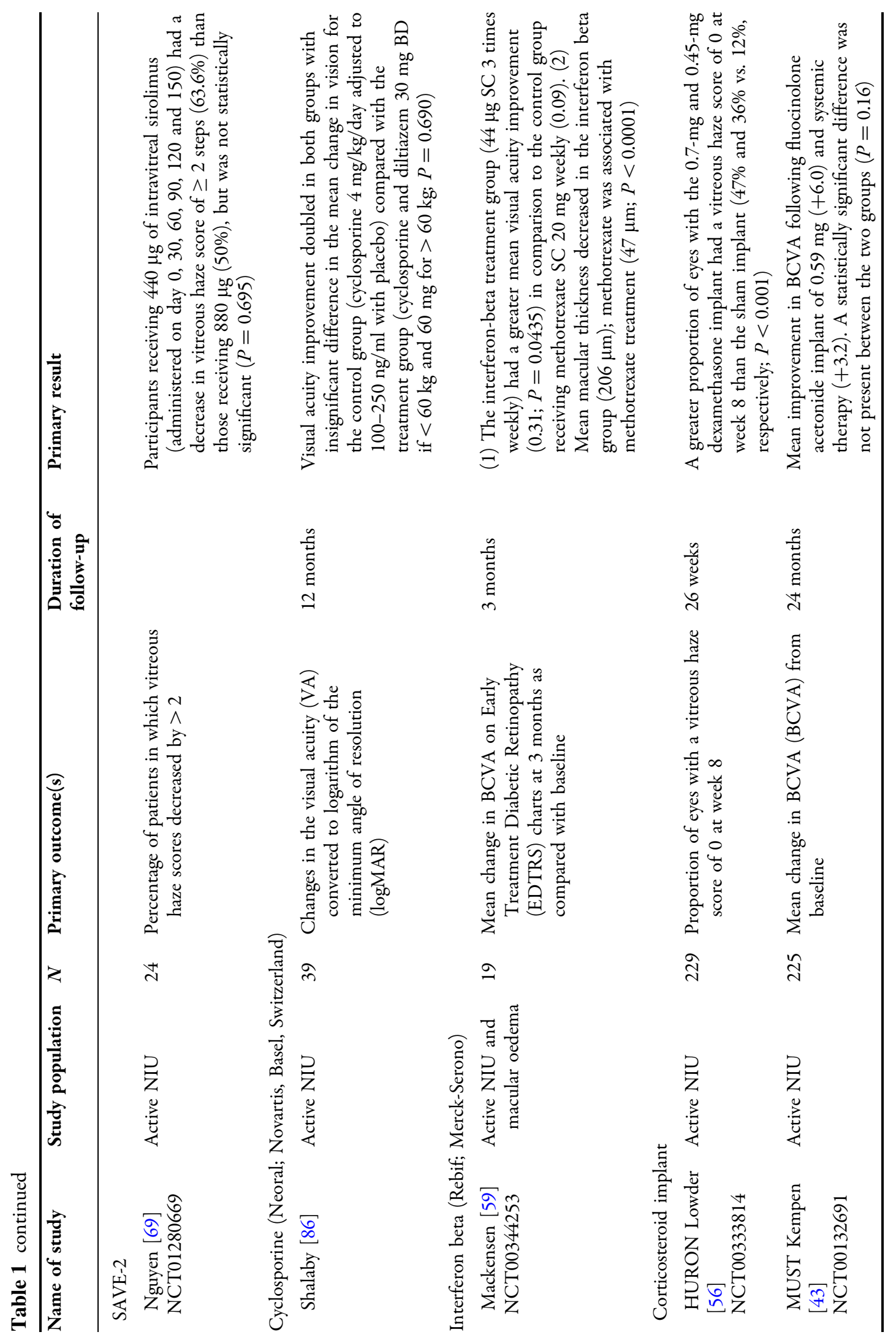




\section{TNF $\alpha$ Inhibitors}

Of the five available TNF $\alpha$ inhibitors (TNFi) in clinical use, adalimumab (Humira; AbbVie, North Chicago, IL, USA) has USFDA and European Medicines Agency (EMA) approval in adults with uveitis refractory to corticosteroids. Adalimumab is a subcutaneously administered, fully humanised anti-TNF $\alpha$ monoclonal antibody. It is usually given every 2 weeks. Other TNFi include infliximab, certolizumab, golimumab and etanercept.

\section{Infliximab}

Infliximab (Remicade, Janssen Biotech Inc., Horsham, PA, USA) is a human-mouse chimeric IgG monoclonal antibody directed at TNF $\alpha$ in both soluble and transmembrane forms. It is administered intravenously and was the first TNF $\alpha$ inhibitor to be used in uveitis. The evidence base for infliximab principally consists of small prospective open-label trials in $\mathrm{BD}$, in which adjunctive use of infliximab led to rapid remission in up to $86 \%$ of patients with refractory disease $[1,26]$, a reduction in ocular inflammation scores comparable with the effect of intravenous corticosteroids, and more rapid resolution of cystoid macular edema [61]. Infliximab is now recommended for sight-threatening ocular disease secondary to $\mathrm{BD}$ as a first- or second-line therapy, although it is only licensed for first-line treatment in Japan [52]. For ocular inflammatory diseases as a whole, the efficacy of infliximab has been estimated at $77 \%$ overall based on a single prospective trial [90]. Other smaller studies have also reported efficacy with infliximab for juvenile idiopathic arthritis (JIA) uveitis and birdshot retinochoroidopathy $[3,42]$. Treatment with systemic infliximab carries a higher adverse event rate than for other TNF $\alpha$ inhibitors, mainly due to infusion reactions which are attributed to immunogenicity of the mouse component of the antibody. Interestingly, a pilot study of intravitreal infliximab for NIU showed limited efficacy with respect to either vitreous haze or resolution of cystoid macular oedema [21]. Therefore, in summary, infliximab's chief application outside BD is usually limited to patients in whom adalimumab therapy has been unsuccessful and potentially, as rescue therapy.

\section{Adalimumab}

Within the last 2 years, two international, multicenter, placebo-controlled, randomized controlled trials (RCTs) of adalimumab in adults with uveitis involving the posterior segment (VISUAL I and VISUAL II trials) $[40,68]$ and one multicenter RCT in children with JIA uveitis (SYCAMORE trial) [78] have been published. All three reached their primary endpoints, but, notably, the SYCAMORE trial was halted at the interim analysis stage due to the clear benefit of adalimumab and methotrexate compared with methotrexate alone $(27 \%$ vs. $60 \%$ treatment failures). VISUAL I studied active uveitis while VISUAL II studied quiescent uveitis which was dependent upon high doses of corticosteroids. Both trials showed that, compared with placebo, treatment with adalimumab was associated with statistically significant increase in median time to treatment failure, a comparative reduction in the number of uveitis treatment failures $(28 \%$ reduction in treatment failure rate in VISUAL I and $20 \%$ in VISUAL II), an approximate halving of the risk of treatment failure and an overall visual quality of life benefit. Adalimumab was well-tolerated overall and the rate of adverse events fell within the expected range. As a result of these studies, adalimumab is now licensed for the treatment of uveitis. In Europe, it is licensed where corticosteroid-sparing is required, or where patients are refractory or intolerant of corticosteroids.

It is worthwhile noting that the VISUAL trials were principally placebo-controlled trials where a small proportion of patients were also treated with conventional immunosuppressive agents. In order to establish its place within the treatment options available, a head-to-head comparison with standard immunosuppression will be necessary. At the time of writing, there is a single phase IV study of the long-term safety and efficacy of adalimumab which is due to report its findings [91]. 
Regional delivery of adalimumab is also under evaluation following a small pilot study which indicated that four weekly injections of $1.5 \mathrm{mg}$ intravitreal adalimumab was successful in inducing remission in six out of seven patients studied without any safety concern [29]. In contrast, a trial of a topically administered antibody fragment against TNF $\alpha$ for HLA-B27-associated anterior uveitis was terminated prematurely for reasons which were undisclosed (www.clinicaltrials.gov NCT00823173).

\section{Certolizumab Pegol}

Certolizumab pegol (Cimzia, UCB Pharma, Brussels, Belgium) is a Fab fragment of a humanised monoclonal anti-TNF $\alpha$ antibody conjugated to polyethylene glycol (PEG) which is administered by subcutaneous injection on a bi-weekly basis. The results of a double-blind, placebo-controlled RCT of certolizumab for anterior uveitis flares associated with spondyloarthropathy showed a lower rate of flares associated with certolizumab, but the result is difficult to interpret because only patients with a past history of uveitis developed uveitis during the trial and, by chance, the placebo group had a greater number of patients with previous uveitis [81].

\section{Golimumab}

Golimumab is a fully humanised monoclonal anti-TNFa antibody approved for use in rheumatoid arthritis (Simponi, Janssen Biotech Inc., PA, USA). It has demonstrated potential efficacy in controlling refractory anterior uveitis associated with spondyloarthritis in a small study [8] and the results of an RCT examining its efficacy in preventing ocular inflammation in spondylarthropathy is awaited (www. clinicaltrials.gov NCT01668004).

\section{Etanercept}

Etanercept (Enbrel, Amgen Inc., Thousand Oaks, CA, USA) is a recombinant fusion protein of the TNF $\alpha$ receptor and the IgG1 Fc region, acting as a decoy receptor to inhibit TNF $\alpha$. It is delivered via subcutaneous injection and it has been associated with increased uveitis flares. There is no evidence to support its use in uveitis.

\section{BEYOND ANTI-TNFA AGENTS}

Despite a generally high degree of clinical effectiveness of TNFi in the short to medium term, some patients do not respond or may experience declining therapeutic response with successive doses, known as tachyphylaxis. Tachyphylaxis has been attributed to anti-infliximab antibodies which are associated with reduced serum levels and activity of infliximab. This has been observed to occur with prevalence rates between $6.4 \%$ and $16 \%$ in inflammatory bowel disease (IBD) patients $[5,12,31,82]$ although the rates have not been ascertained in uveitis patients. Antibodies to TNFi have also been observed following treatment with humanised agents, adalimumab (3.8\% of treated patients) and certolizumab pegol $(12 \%$ of treated patients) in IBD and rheumatoid arthritis [83, 84]. Significant adverse events may also necessitate discontinuation of treatment, such as drug-induced lupus-like reaction with infliximab [22, 89] or reactivation of latent tuberculosis (TB) [47]. For these reasons, multiple approaches to control uveitis are essential.

\section{Type I Interferons}

Type I interferons (IFN) are naturally occurring cytokines which help to regulate the immune system, including exerting an anti-proliferative effect on T-cells and upregulating the production of regulatory T-cells [54]. Type I IFNs consist of a number of IFN $\alpha$ isotypes and IFN $\beta$. Subcutaneous administration of IFN $\alpha 2 \mathrm{a}$ as a systemic immunomodulatory therapy was first studied in BD in 1986 [95]. IFN $\alpha 2$ has been studied in small non-randomised studies which indicated that it is effective in the management of Behçet's uveitis and may result in long-term 
remission following treatment cessation [15]. A small RCT of 19 patients with intermediate uveitis or uveitis associated with multiple sclerosis treated with either subcutaneous IFN $\beta$ or methotrexate showed significant reduction in macular oedema and visual acuity with IFN $\beta$ but not methotrexate [59]. Unlike TNFi, interferons are not associated with the risk of $\mathrm{TB}$ reactivation which is of particular advantage in the treatment of $\mathrm{BD}$ in areas of high $\mathrm{TB}$ endemicity. It also has a role in the management of patients with macular oedema unresponsive to TNFi. However, one of the practical limitations of using interferons are their side-effects, including flu-like symptoms, risk of depression and, rarely, reports of suicidal ideation [46].

\section{Anti-Interleukin 6}

Interleukin 6 (IL-6) is expressed by T-cells, B-cells and monocytes, and potently induces several other inflammatory mediators as well as stimulating production of IL-17-producing helper T-cells (Th17), an important lineage of lymphocytes in the perpetuation of inflammation and tissue injury in many autoimmune diseases [24, 48, 62, 63]. IL-6 has been shown to be responsible for ocular inflammation in the mouse experimental autoimmune uveitis (EAU) model [101]. Cytokine profiling studies have shown serum IL-6 levels to be elevated in a variety of active or chronic NIU [30, 49, 101]. Tocilizumab (RoActemra, Roche AG, Basel, Switzerland) is a humanised mouse monoclonal antibody inhibitor of IL-6 receptor. It is currently licensed for moderate to severe rheumatoid arthritis, which is refractory to TNFi and also recommended for use in systemic JIA $[87,100]$. The STOP-Uveitis Study, a 6-month study of 37 patients treated with one of two intravenous doses (either 4 or $8 \mathrm{mg}$ per $\mathrm{kg}$ ) of tocilizumab for posterior NIU demonstrated that the therapy was well-tolerated and associated with a reduction in vitreous haze and cystoid macular oedema at both doses [85]. Other IL-6 inhibitors are also under development which may become relevant for uveitis in the future [55].

\section{Anti-Interleukin 12 and 23}

IL-12 and IL-23 promote differentiation of T-cells into and survival Th17 cells [64, 93]. IL-23 is associated with uveitis in the EAU mouse model and in humans with VKH disease and BD [9, 10, 58]. Ustekinumab (Stelara, Janssen Biotech Inc., Horsham, PA, USA) is a monoclonal antibody directed at a common subunit of IL-12 and IL-23, called p-40, thereby blocking the effects of these cytokines on T-cells and antigen-presenting cells. Studies of ustekinumab for uveitis are at the phase II stage (www. clinicaltrials.gov NCT01647152).

\section{Anti-Interleukin 17}

IL-17 has been implicated as a key pro-inflammatory cytokine in autoimmune diseases, including uveitis, and therefore represents a potential target in the treatment of uveitis $[7-10,16,30,50,57,88]$. So far, three randomised phase III trials of subcutaneous secukinumab (Cosentyx, Novartis Pharmaceutical, Basel, Switzerland), a fully human monoclonal antibody against IL-17A, have shown no significant benefit in NIU [19]. However, intravenous delivery of secukinumab in a phase II randomised study suggests that the route of delivery is well-tolerated and response rates are superior to subcutaneous administration [51]. Currently, there are no active phase III trials evaluating the efficacy of secukinumab in NIU.

\section{Anti-Interleukin 1}

IL-1 $\beta$ belongs to the IL- 1 family of pro-inflammatory cytokines, which is associated with facilitating acute and chronic inflammation, and is secreted by activated macrophages and B-cells [74]. IL-1 $\beta$ is best known for its role in the pathogenesis of disorders involving the inflammasome, such as cryopyrin-associated periodic syndrome (CAPS), but is also implicated in JIA and BD [25, 27, 33, 77]. Gevokizumab (XOMA Corporation, Berkeley, CA, USA) is a recombinant humanised monoclonal IgG2 against IL-1 $\beta$ and inhibits its ability to signal a downstream cascade of inflammatory 
events [37]. Several commercially sponsored studies have been withdrawn without completion; in one study at least, the primary outcome was not reached.

\begin{abstract}
Abatacept
The activation of $T$-cells by antigen-presenting cells requires co-stimulation through major histocompatibility complex (MHC), and interaction between $T$-cell CD28 and antigen-presenting cell receptors CD80 or CD86. Abatacept (Orencia; BMS., New York, NY, USA) is a fusion protein of the extracellular domain of cytotoxic $T$ lymphocyte antigen 4 (CTLA-4) and the Fc portion of IgG1, which binds CD80 and CD86, thereby inhibiting T-cell activation [36]. Data evaluating the efficacy of abatacept in uveitis is currently limited to case reports of its usage in JIA $[2,45,102]$, although an open-label trial is underway (www.clinicaltrials. gov NCT01279954).
\end{abstract}

\section{BIOSIMILARS}

Whether as part of a single-payer system, through insurance or as individuals, the high costs associated with biologic immunomodulatory therapies can impact access. Biosimilar therapies are biological products which are pharmacologically highly similar to an approved biological pharmaceutical 'reference' product, but due to differences which arise from the manufacturing processes, they are not exact copies and, thus, not 'generic' drugs. Biosimilars are cheaper than the innovator molecule, potentially increasing the number of patients who may be treated.

Once approved by a regulatory agency for rigorous demonstration of equivalent pharmacokinetics, effectiveness, safety and immunogenicity to the reference product through an RCT and in vitro studies, a biosimilar acquires the same licensed indications as those of the reference product within a specific regulated region [39]. Of the TNFi biosimilars, CT-P13 (Inflectra or Remsima, Pfizer Inc., New York City, USA), an infliximab biosimilar, is amongst the most widely studied biosimilars and demonstrates a high degree of similarity to the reference product [39]. The adalimumab biosimilar, ABP501 (AMJEVITA, Amgen Inc.), has recently gained regulatory body approval in Europe, having been the subject of RCTs for psoriasis and rheumatoid arthritis [11]. Careful selection of the biosimilar drug and evaluation of safety and clinical efficacy will be necessary to provide the evidence base to demonstrate bioequivalence to biologic reference products in uveitis.

The cost-savings vary between drugs, manufacturers and regions. To illustrate current potential cost savings using infliximab as an example; in the UK the cost of a 100-mg vial of the innovator drug, Remicade (Janssen Biotech Inc., PA, USA), cited in the British National Formulary is $£ 419.62$ per $100 \mathrm{mg}$ [41]. In the USA, the Lexicomp database cites the cost of $100 \mathrm{mg}$ of Remicaide as $\$ 1401.38$ per $100 \mathrm{mg}$ [53]. Inflectra (Pfizer, NY, USA) and Remsima (Hospira, IL, USA) are brands of infliximab biosimilars which costs of $£ 377.66$ for a 100 -mg vial in the UK and \$1135.54 for a 100-mg vial in the USA (Supplementary Materials).

\section{REGIONAL TREATMENTS}

Although a detailed description is beyond the brief of this review, the role of regional treatments is the subject of a great deal of interest within the ophthalmic community. The HURON trial demonstrated the efficacy and safety of Ozurdex (Allergan Inc., Irvine, CA, USA), an intravitreal implant which biodegrades to release dexamethasone in a sustained manner [56]. In an RCT of 229 patients, vitreous haze was significantly reduced in eyes receiving $0.7 \mathrm{mg}$ or $0.35 \mathrm{mg}$ of Ozurdex (47\% and 36\%) in comparison to sham injections (12\%). The MUST trial demonstrated equivalence in efficacy between the fluocinolone acetonide implant and systemic therapy at 2 years, as both showed similar improvements in visual acuity (+6.0 and +3.2 , respectively) [43]. At the 7-year follow-up, patients on systemic therapy had better visual outcomes than those who received fluocinolone acetonide, principally due to the side-effects of corticosteroids within the eye $[43,44]$. 
A potential future direction for development of regional therapies is the mammalian target of rapamycin (mTOR) inhibitor, sirolimus (Rapamune, Pfizer Inc., New York City, NY, USA). Sirolimus suppresses T-cell proliferation and differentiation $[14,96]$. The SAKURA trial demonstrated that intravitreal sirolimus was able to reduce inflammation in NIU without the high rate of adverse events associated with systemic administration $[67,69]$. One potential limitation of these studies is the absence of a placebo arm, which prevents accurate quantification of efficacy or adverse events.

\section{CONCLUSION AND FUTURE DIRECTIONS}

We have witnessed a rapid growth in the armamentarium available for controlling autoimmune uveitis and, crucially, there are more treatments in the translational and developmental pipeline than at any previous time for uveitis. The expanding landscape of uveitis therapies has grown to encompass not only corticosteroids and conventional immunosuppressants, but also biologic therapies and regional treatments. The successful licensing of the TNF $\alpha$ inhibitor, adalimumab, represents a key milestone in the development of systemic therapies for uveitis as it was the first new drug to be licensed in several global regions for uveitis since corticosteroids in the 1960s. Novel treatments for the near future include inhibitors of IL-6, IL-23 and mTOR, whilst a number of others are in early phase trials. Other potentially exciting developments include complement-directed therapies which are currently at the proof-of-concept stage for uveitis (clinicaltrials.gov NCT01526889) [99]. Signal transduction inhibitors collectively form another emerging class of biologic therapy. These molecules were first developed for haematological diseases such as chronic myeloid leukaemia [73] and myelofibrosis [32, 97], and have had recent success in treating rheumatoid arthritis [23]. This so-called 'small molecule' class of biologic therapies target intracellular signalling enzymes such as those in the Janus kinase/signal transducer activating
(JAK/STAT) pathway which mediate the intracellular actions of cytokines within immune cells. The selective JAK1 inhibitor, filgotinib (Galapagos NV, Mechelen, Belgium), is due to be evaluated in an international phase III trial in NIU (www.clinicalTrials.gov NCT02914561).

The rapid developments of novel uveitis therapies have been made possible by a combination of factors, including standardisation of uveitis classification and research outcome measures [38], international collaboration to recruit well-powered studies to conduct clinical trials and the interest of pharmaceutical companies in widening the licensing of new treatments to include uveitis. Optimisation of clinical management will rely upon long-term evaluation of new therapies to monitor safety and disease-specific outcomes. Registry data will be required to capture the incidence of infections and cancer whilst on these newer therapies. The consequence of all of these efforts and closer partnership with patients through clinical trials is that we are progressing towards the aspiration for a range of treatment options which reduce the historical over-dependence on corticosteroids, preserve vision and positively impact quality of life.

\section{ACKNOWLEDGEMENTS}

We thank Dr. Katherine Fallano, MD and Dr. Brittany Simmons for providing assistance with the content of Table 2 (Supplementary Materials).

Funding. No funding or sponsorship was received for this study or publication of this article.

Disclosures. Srilakshmi M. Sharma and Dun Jack Fu have nothing to disclose. Kanmin Xue is funded by the University of Oxford and National Institutes for Health Research.

Compliance with Ethics Guidelines. This article is based on previously conducted studies and does not involve any new studies of human or animal subjects performed by any of the authors. 
Data Availability. Data analyzed during this study are referenced in this published article; clinical trials since 2011 which have been discussed within this article have been additionally summarized within the tables and supplementary information files.

Open Access. This article is distributed under the terms of the Creative Commons Attribution-NonCommercial 4.0 International License (http://creativecommons.org/licenses/ by-nc/4.0/), which permits any noncommercial use, distribution, and reproduction in any medium, provided you give appropriate credit to the original author(s) and the source, provide a link to the Creative Commons license, and indicate if changes were made.

Author Contributions All named authors meet the International Committee of Medical Journal Editors (ICMJE) criteria for authorship for this manuscript, take responsibility for the integrity of the work as a whole and have given final approval for the version to be published.

\section{REFERENCES}

1. Al-Rayes H, Al-Swailem R, Al-Balawi M, Al-Dohayan N, Al-Zaidi S, Tariq M. Safety and efficacy of infliximab therapy in active Behcet's uveitis: an open-label trial. Rheumatol Int. 2008;29(1):53-7.

2. Angeles-Han S, Flynn T, Lehman T. Abatacept for refractory juvenile idiopathic arthritis-associated uveitis- a case report. J Rheumatol. 2008;35(9):1897-8.

3. Artornsombudh P, Gevorgyan O, Payal A, Siddique SS, Foster CS. Infliximab treatment of patients with birdshot retinochoroidopathy. Ophthalmology. 2013;120(3):588-92.

4. Baarsma GS. The epidemiology and genetics of endogenous uveitis: a review. Curr Eye Res. 1992;11(Suppl):1-9.

5. Baert F, Noman M, Vermeire S, Van Assche G, D'Haens G, Carbonez A, Rutgeerts P. Influence of immunogenicity on the long-term efficacy of infliximab in Crohn's disease. $\mathrm{N}$ Engl J Med. 2003;348(7):601-8.
6. Barry RJ, Nguyen QD, Lee RW, Murray PI, Denniston AK. Pharmacotherapy for uveitis: current management and emerging therapy. Clin Ophthalmol. 2014;8:1891-911.

7. Catana CS, Berindan Neagoe I, Cozma V, Magdas C, Tabaran F, Dumitrascu DL. Contribution of the IL-17/IL-23 axis to the pathogenesis of inflammatory bowel disease. World J Gastroenterol. 2015;21(19):5823-30.

8. Calvo-Río V, Blanco R, Santos-Gómez M, RubioRomero E, Cordero-Coma M, Gallego- Flores A, Veroz R, Torre I, Hernández FF, Atanes A, Loricera J, González-Vela MC, Palmou N, Hernández JL, González-Gay MA. Golimumab in refractory uveitis related to spondyloarthritis. Multicenter study of 15 patients. Semin Arthritis Rheum. 2016;46(1):95-101.

9. Chi W, Yang P, Li B, Wu C, Jin H, Zhu X, Chen L, Zhou H, Huang X, Kijlstra A. IL-23 promotes CD4+ $\mathrm{T}$ cells to produce IL-17 in Vogt-Koyanagi-Harada disease. J Allergy Clin Immunol. 2007;119(5):1218-24.

10. Chi W, Zhu X, Yang P, Liu X, Lin X, Zhou H, Huang $X$, Kijlstra A. Upregulated IL-23 and IL-17 in Behcet patients with active uveitis. Invest Ophthalmol Vis Sci. 2008;49(7):3058-64.

11. Cohen S, Genovese MC, Choy E, Perez-Ruiz F, Matsumoto A, Pavelka K, Pablos JL, Rizzo W, Hrycaj P, Zhang N, Shergy W, Kaur P. Efficacy and safety of the biosimilar ABP 501 compared with adalimumab in patients with moderate to severe rheumatoid arthritis: a randomised, double-blind, phase III equivalence study. Ann Rheum Dis. 2017;76(10):1679-87.

12. Colombel JF, Sandborn WJ, Reinisch W, Mantzaris GJ, Kornbluth A, Rachmilewitz D, Lichtiger S, D'Haens G, Diamond RH, Broussard DL, Tang KL, van der Woude CJ, Rutgeerts P, Group SS. Infliximab, azathioprine, or combination therapy for Crohn's disease. N Engl J Med. 2010;362(15):1383-95.

13. Curnow SJ, Scheel-Toellner D, Jenkinson W, Raza K, Durrani OM, Faint JM, Rauz S, Wloka K, Pilling D, Rose-John S, Buckley CD, Murray PI, Salmon M. Inhibition of $\mathrm{T}$ cell apoptosis in the aqueous humor of patients with uveitis by IL-6/soluble IL- 6 receptor trans-signaling. J Immunol. 2004;173(8):5290-7.

14. Dasari TW, Patel B, Saucedo JF. Systematic review of effectiveness of oral sirolimus after bare-metal stenting of coronary arteries for prevention of in-stent restenosis. Am J Cardiol. 2013;112(9):1322-7.

15. Deuter CM, Zierhut M, Möhle A, Vonthein R, Stöbiger N, Kötter I. Long-term remission after cessation of interferon- $\alpha$ treatment in patients with 
severe uveitis due to Behçet's disease. Arthritis Rheum. 2010;62(9):2796-805.

16. Di Cesare A, Di Meglio P, Nestle FO. The IL-23/Th17 axis in the immunopathogenesis of psoriasis. J Invest Dermatol. 2009;129(6):1339-50.

17. Dick AD, McMenamin PG, Körner H, Scallon BJ, Ghrayeb J, Forrester JV, Sedgwick JD. Inhibition of tumor necrosis factor activity minimizes target organ damage in experimental autoimmune uveoretinitis despite quantitatively normal activated $\mathrm{T}$ cell traffic to the retina. Eur J Immunol. 1996;26(5):1018-25.

18. Dick AD, Forrester JV, Liversidge J, Cope AP. The role of tumour necrosis factor (TNF-alpha) in experimental autoimmune uveoretinitis (EAU). Prog Retin Eye Res. 2004;23(6):617-37.

19. Dick AD, Tugal-Tutkun I, Foster $S$, Zierhut $M$, Melissa Liew SH, Bezlyak V, Androudi S. Secukinumab in the treatment of noninfectious uveitis: results of three randomized, controlled clinical trials. Ophthalmology. 2013;120(4):777-87.

20. Durrani OM, Tehrani NN, Marr JE, Moradi P, Stavrou P, Murray PI. Degree, duration, and causes of visual loss in uveitis. $\mathrm{Br} \mathrm{J}$ Ophthalmol. 2004;88(9):1159-62.

21. Farvardin M, Afarid M, Shahrzad S. Long-term effects of intravitreal infliximab for treatment of sight-threatening chronic noninfectious uveitis. J Ocul Pharmacol Ther. 2012;28(6):628-31.

22. Fleischmann R, Yocum D. Does safety make a difference in selecting the right TNF antagonist? Arthritis Res Ther. 2004;6(Suppl 2):S12-8.

23. Fleischmann R, Kremer J, Cush J, Schulze-Koops H, Connell CA, Bradley JD, Gruben D, Wallenstein GV, Zwillich SH, Kanik KS, Investigators OS. Placebo-controlled trial of tofacitinib monotherapy in rheumatoid arthritis. $\mathrm{N}$ Engl $\mathrm{J}$ Med. 2012;367(6):495-507.

24. Fujimoto $M$, Nakano $M$, Terabe $F$, Kawahata $H$, Ohkawara T, Han Y, Ripley B, Serada S, Nishikawa T, Kimura A, Nomura S, Kishimoto T, Naka T. The influence of excessive IL-6 production in vivo on the development and function of Foxp3+ regulatory T cells. J Immunol. 2011;186(1):32-40.

25. Gattorno M, Piccini A, Lasiglie D, Tassi S, Brisca G, Carta S, Delfino L, Ferlito F, Pelagatti MA, Caroli F, Buoncompagni A, Viola S, Loy A, Sironi M, Vecchi A, Ravelli A, Martini A, Rubartelli A. The pattern of response to anti-interleukin-1 treatment distinguishes two subsets of patients with systemic-onset juvenile idiopathic arthritis. Arthritis Rheum. 2008;58(5):1505-15.
26. Giardina A, Ferrante A, Ciccia F, Vadalà M, Giardina E, Triolo G. 1 year study of efficacy and safety of infliximab in the treatment of patients with ocular and neurological Behçet's disease refractory to standard immunosuppressive drugs. Rheumatol Int. 2011;31(1):33-7.

27. Goldbach-Mansky R, Dailey NJ, Canna SW, Gelabert A, Jones J, Rubin BI, Kim HJ, Brewer C, Zalewski C, Wiggs E, Hill S, Turner ML, Karp BI, Aksentijevich I, Pucino F, Penzak SR, Haverkamp MH, Stein L, Adams BS, Moore TL, Fuhlbrigge RC, Shaham B, Jarvis JN, O'Neil K, Vehe RK, Beitz LO, Gardner G, Hannan WP, Warren RW, Horn W, Cole JL, Paul SM, Hawkins PN, Pham TH, Snyder C, Wesley RA, Hoffmann SC, Holland SM, Butman JA, Kastner DL. Neonatal-onset multisystem inflammatory disease responsive to interleukin-1beta inhibition. N Engl J Med. 2006;355(6):581-92.

28. Gritz DC, Wong IG. Incidence and prevalence of uveitis in Northern California; the Northern California Epidemiology of Uveitis Study. Ophthalmology. 2004;111(3):491-500 (Discussion 500).

29. Hamam RN, Barikian AW, Antonios RS, Abdulaal MR, Alameddine RM, El Mollayess G, Mansour AM. Intravitreal adalimumab in active noninfectious uveitis: a pilot study. Ocul Immunol Inflamm. 2016;24(3):319-26.

30. Hamzaoui K, Hamzaoui A, Guemira F, Bessioud M, Hamza M, Ayed K. Cytokine profile in Behcet's disease patients. Relationship with disease activity. Scand J Rheumatol. 2002;31(4):205-10.

31. Hanauer SB, Wagner CL, Bala M, Mayer L, Travers S, Diamond RH, Olson A, Bao W, Rutgeerts P. Incidence and importance of antibody responses to infliximab after maintenance or episodic treatment in Crohn's disease. Clin Gastroenterol Hepatol. 2004;2(7):542-53.

32. Harrison C, Kiladjian JJ, Al-Ali HK, Gisslinger H, Waltzman R, Stalbovskaya V, McQuitty M, Hunter DS, Levy R, Knoops L, Cervantes F, Vannucchi AM, Barbui T, Barosi G. JAK inhibition with ruxolitinib versus best available therapy for myelofibrosis. N Engl J Med. 2012;366(9):787-98.

33. Hoffman HM, Throne ML, Amar NJ, Sebai M, Kivitz AJ, Kavanaugh A, Weinstein SP, Belomestnov P, Yancopoulos GD, Stahl N, Mellis SJ. Efficacy and safety of rilonacept (interleukin-1 Trap) in patients with cryopyrin-associated periodic syndromes: results from two sequential placebo-controlled studies. Arthritis Rheum. 2008;58(8):2443-52.

34. Hogan AC, McAvoy CE, Dick AD, Lee RW. Long-term efficacy and tolerance of tacrolimus for the treatment of uveitis. Ophthalmology. 2007;114(5):1000-6. 
35. Horai R, Caspi RR. Cytokines in autoimmune uveitis. J Interferon Cytokine Res. 2011;31(10):733-44.

36. Iannone F, Lapadula G. The inhibitor of costimulation of T cells: abatacept. J Rheumatol Suppl. 2012;89:100-2.

37. Issafras $\mathrm{H}$, Corbin JA, Goldfine ID, Roell MK. Detailed mechanistic analysis of gevokizumab, an allosteric anti-IL-1beta antibody with differential receptor-modulating properties. J Pharmacol Exp Ther. 2014;348(1):202-15.

38. Jabs DA, Nussenblatt RB, Rosenbaum JT, Group S. o. U. N. S. W. Standardization of uveitis nomenclature for reporting clinical data. Results of the First International Workshop. Am J Ophthalmol. 2005;140(3):509-16.

39. Jacobs I, Petersel D, Isakov L, Lula S, Lea Sewell K. Biosimilars for the treatment of chronic inflammatory diseases: a systematic review of published evidence. BioDrugs. 2016;30(6):525-70.

40. Jaffe GJ, Dick AD, Brézin AP, Nguyen QD, Thorne JE, Kestelyn P, Barisani-Asenbauer T, Franco P, Heiligenhaus A, Scales D, Chu DS, Camez A, Kwatra NV, Song AP, Kron M, Tari S, Suhler EB. Adalimumab in patients with active noninfectious uveitis. N Engl J Med. 2016;375(10):932-43.

41. Joint Formulary C. Bnf: September 2015-March 2016. 70th ed. London: British Medical Assn; 2015.

42. Kahn P, Weiss M, Imundo LF, Levy DM. Favorable response to high-dose infliximab for refractory childhood uveitis. Ophthalmology. 2006;113(5):860-4.

43. Kempen JH, Altaweel MM, Holbrook JT, Jabs DA, Louis TA, Sugar EA, Thorne JE, Group M. U. S. T. M. T. R. Randomized comparison of systemic anti-inflammatory therapy versus fluocinolone acetonide implant for intermediate, posterior, and panuveitis: the multicenter uveitis steroid treatment trial. Ophthalmology. 2011;118(10):1916-26.

44. Kempen JH, Altaweel MM, Holbrook JT, Sugar EA, Thorne JE, Jabs DA, Group W. C. f.t. M. U.S. T. M. T. a. F.-u. S. R. Association between long-lasting intravitreous fluocinolone acetonide implant vs systemic anti-inflammatory therapy and visual acuity at 7 years among patients with intermediate, posterior, or panuveitis. JAMA. 2017;317(19):1993-2005.

45. Kenawy N, Cleary G, Mewar D, Beare N, Chandna A, Pearce I. Abatacept: a potential therapy in refractory cases of juvenile idiopathic arthritis-associated uveitis. Graefes Arch Clin Exp Ophthalmol. 2011;249(2):297-300.

46. Keskin Y, Seyahi E, Poyraz C, Ugurlu S, Ozyazgan Y, Yazici H. Interferon alfa-associated depression in patients with Behçet's syndrome: a prospective controlled study. Clin Exp Rheumatol. 2014;32(4 Suppl 84):S175.

47. Kim JS, Knickelbein JE, Nussenblatt RB, Sen HN. Clinical trials in noninfectious uveitis. Int Ophthalmol Clin. 2015;55(3):79-110.

48. Kishimoto $\mathrm{T}$. Interleukin-6: from basic science to medicine -40 years in immunology. Annu Rev Immunol. 2005;23:1-21.

49. Kramer M, Monselise Y, Bahar I, Cohen Y, Weinberger D, Goldenberg-Cohen N. Serum cytokine levels in active uveitis and remission. Curr Eye Res. 2007;32(7-8):669-75.

50. Leipe J, Grunke M, Dechant C, Reindl C, Kerzendorf U, Schulze-Koops H, Skapenko A. Role of Th17 cells in human autoimmune arthritis. Arthritis Rheum. 2010;62(10):2876-85.

51. Letko E, Yeh S, Foster CS, Pleyer U, Brigell M, Grosskreutz CL, Group A. A. S. Efficacy and safety of intravenous secukinumab in noninfectious uveitis requiring steroid-sparing immunosuppressive therapy. Ophthalmology. 2015;122(5):939-48.

52. Levy-Clarke G, Jabs DA, Read RW, Rosenbaum JT, Vitale A, Van Gelder RN. Expert panel recommendations for the use of anti-tumor necrosis factor biologic agents in patients with ocular inflammatory disorders. Ophthalmology. 2014;121(3):785-96.

53. Lexicomp. Wolters Kluwer Health, I. R., IL. Lexi-Drugs, Lexicomp. Wolters Kluwer Health, Inc. Riverwoods, IL. Available at: https://online.lexi. com/. Accessed 11 Sept 2017.

54. Lightman S, Taylor SR, Bunce C, Longhurst H, Lynn W, Moots R, Stanford M, Tomkins-Netzer O, Yang D, Calder VL, Haskard DO. Pegylated interferon- $\alpha-2 b$ reduces corticosteroid requirement in patients with Behçet's disease with upregulation of circulating regulatory T cells and reduction of Th17. Ann Rheum Dis. 2015;74(6):1138-44.

55. Lin P. Targeting interleukin-6 for noninfectious uveitis. Clin Ophthalmol. 2015;9:1697-702.

56. Lowder C, Belfort R, Lightman S, Foster CS, Robinson MR, Schiffman RM, Li XY, Cui H, Whitcup SM, Group, O. H. S. Dexamethasone intravitreal implant for noninfectious intermediate or posterior uveitis. Arch Ophthalmol. 2011;129(5):545-53.

57. Lowes MA, Kikuchi T, Fuentes-Duculan J, Cardinale I, Zaba LC, Haider AS, Bowman EP, Krueger JG. Psoriasis vulgaris lesions contain discrete populations of Th1 and Th17 T cells. J Invest Dermatol. 2008;128(5):1207-11. 
58. Luger D, Silver PB, Tang J, Cua D, Chen Z, Iwakura Y, Bowman EP, Sgambellone NM, Chan CC, Caspi RR. Either a Th17 or a Th1 effector response can drive autoimmunity: conditions of disease induction affect dominant effector category. J Exp Med. 2008;205(4):799-810.

59. Mackensen F, Jakob E, Springer C, Dobner BC, Wiehler U, Weimer P, Rohrschneider K, Fiehn C, Max R, Storch-Hagenlocher B, Becker MD. Interferon versus methotrexate in intermediate uveitis with macular edema: results of a randomized controlled clinical trial. Am J Ophthalmol. 2013;156(3):478-86.

60. Maini R, St Clair EW, Breedveld F, Furst D, Kalden J, Weisman M, Smolen J, Emery P, Harriman G, Feldmann $M$, Lipsky P. Infliximab (chimeric anti-tumour necrosis factor alpha monoclonal antibody) versus placebo in rheumatoid arthritis patients receiving concomitant methotrexate: a randomised phase III trial. ATTRACT Study Group. Lancet. 1999;354(9194):1932-9.

61. Markomichelakis N, Delicha E, Masselos S, Fragiadaki K, Kaklamanis $\mathrm{P}$, Sfikakis PP. A single infliximab infusion vs corticosteroids for acute panuveitis attacks in Behçet's disease: a comparative 4-week study. Rheumatology (Oxford). 2011;50(3):593-7.

62. Matzinger P. The danger model: a renewed sense of self. Science. 2002;296(5566):301-5.

63. Miossec P, Korn T, Kuchroo VK. Interleukin-17 and type 17 helper $\mathrm{T}$ cells. $\mathrm{N}$ Engl $\mathrm{J}$ Med. 2009;361(9):888-98.

64. Murphy KM, Reiner SL. The lineage decisions of helper $\mathrm{T}$ cells. Nat Rev Immunol. 2002;2(12):933-44.

65. Murphy CC, Greiner K, Plskova J, Duncan L, Frost NA, Forrester JV, Dick AD. Cyclosporine vs tacrolimus therapy for posterior and intermediate uveitis. Arch Ophthalmol. 2005;123(5):634-41.

66. Nguyen QD, Hatef E, Kayen B, Macahilig CP, Ibrahim M, Wang J, Shaikh O, Bodaghi B. A cross-sectional study of the current treatment patterns in noninfectious uveitis among specialists in the United States. Ophthalmology. 2011;118(1):184-90.

67. Nguyen QD, Merrill PT, Clark WL, Banker AS, Fardeau C, Franco P, LeHoang P, Ohno S, Rathinam SR, Thurau S, Abraham A, Wilson L, Yang Y, Shams N, Sirolimus study Assessing double-masKed Uveitis tReAtment Study, G. Intravitreal Sirolimus for Noninfectious Uveitis: A Phase III Sirolimus Study Assessing Double-masKed Uveitis TReAtment (SAKURA). Ophthalmology. 2016;123(11):2413-23.
68. Nguyen QD, Merrill PT, Jaffe GJ, Dick AD, Kurup SK, Sheppard J, Schlaen A, Pavesio C, Cimino L, Van Calster J, Camez AA, Kwatra NV, Song AP, Kron M, Tari S, Brézin AP. Adalimumab for prevention of uveitic flare in patients with inactive non-infectious uveitis controlled by corticosteroids (VISUAL II): a multicentre, double-masked, randomised, placebo-controlled phase 3 trial. Lancet. 2016;388(10050):1183-92.

69. Nguyen QD, Sadiq MA, Soliman MK, Agarwal A, Do DV, Sepah YJ. The Effect of different dosing schedules of intravitreal sirolimus, a mammalian target of rapamycin (mTOR) inhibitor, in the treatment of non-infectious uveitis (An American Ophthalmological Society Thesis). Trans Am Ophthalmol Soc. 2016;114:T3.

70. Nussenblatt RB. The natural history of uveitis. Int Ophthalmol. 1990;14(5-6):303-8.

71. Nussenblatt RB, Rodrigues MM, Salinas-Carmona MC, Gery I, Cevario S, Wacker W. Modulation of experimental autoimmune uveitis with cyclosporin A. Arch Ophthalmol. 1982;100(7):1146-9.

72. Nussenblatt RB, Palestine AG, Rook AH, Scher I, Wacker WB, Gery I. Treatment of intraocular inflammatory disease with cyclosporin A. Lancet. 1983;2(8344):235-8.

73. O'Brien SG, Guilhot F, Larson RA, Gathmann I, Baccarani M, Cervantes F, Cornelissen JJ, Fischer T, Hochhaus A, Hughes T, Lechner K, Nielsen JL, Rousselot P, Reiffers J, Saglio G, Shepherd J, Simonsson B, Gratwohl A, Goldman JM, Kantarjian H, Taylor K, Verhoef G, Bolton AE, Capdeville R, Druker BJ, Investigators I. Imatinib compared with interferon and low-dose cytarabine for newly diagnosed chronic-phase chronic myeloid leukemia. N Engl J Med. 2003;348(11):994-1004.

74. Ooi KG, Galatowicz G, Calder VL, Lightman SL. Cytokines and chemokines in uveitis: is there a correlation with clinical phenotype? Clin Med Res. 2006;4(4):294-309.

75. Ozyazgan Y, Yurdakul S, Yazici H, Tüzün B, Işçimen A, Tüzün Y, Aktunç T, Pazarli H, Hamuryudan V, Müftüoğlu A. Low dose cyclosporin A versus pulsed cyclophosphamide in Behçet's syndrome: a single masked trial. Br J Ophthalmol. 1992;76(4):241-3.

76. Pasadhika S, Kempen JH, Newcomb CW, Liesegang TL, Pujari SS, Rosenbaum JT, Thorne JE, Foster CS, Jabs DA, Levy-Clarke GA, Nussenblatt RB, Suhler EB. Azathioprine for ocular inflammatory diseases. Am J Ophthalmol. 2009;148(4):500-9.

77. Pascual V, Allantaz F, Arce E, Punaro M, Banchereau J. Role of interleukin-1 (IL-1) in the pathogenesis of systemic onset juvenile idiopathic arthritis and 
clinical response to IL-1 blockade. J Exp Med. 2005;201(9):1479-86.

78. Ramanan AV, Dick AD, Benton D, Compeyrot-Lacassagne S, Dawoud D, Hardwick B, Hickey $H$, Hughes D, Jones A, Woo P, Edelsten C, Beresford MW, Group S. T. M. A randomised controlled trial of the clinical effectiveness, safety and cost-effectiveness of adalimumab in combination with methotrexate for the treatment of juvenile idiopathic arthritis associated uveitis (SYCAMORE Trial). Trials. 2014;15:14.

79. Rathinam SR, Babu M, Thundikandy R, Kanakath A, Nardone N, Esterberg E, Lee SM, Enanoria WT, Porco TC, Browne EN, Weinrib R, Acharya NR. A randomized clinical trial comparing methotrexate and mycophenolate mofetil for noninfectious uveitis. Ophthalmology. 2014;121(10):1863-70.

80. Rodriguez A, Calonge M, Pedroza-Seres M, Akova YA, Messmer EM, D’Amico DJ, Foster CS. Referral patterns of uveitis in a tertiary eye care center. Arch Ophthalmol. 1996;114(5):593-9.

81. Rudwaleit M, Rosenbaum JT, Landewe R, Marzo-Ortega H, Sieper J, van der Heijde D, Davies O, Bartz H, Hoepken B, Nurminen T, Deodhar A. Observed Incidence of uveitis following certolizumab pegol treatment in patients with axial spondyloarthritis. Arthritis Care Res (Hoboken). 2016;68(6):838-44.

82. Rutgeerts P, Sandborn WJ, Feagan BG, Reinisch W, Olson A, Johanns J, Travers S, Rachmilewitz D, Hanauer SB, Lichtenstein GR, de Villiers WJ, Present $\mathrm{D}$, Sands BE, Colombel JF. Infliximab for induction and maintenance therapy for ulcerative colitis. N Engl J Med. 2005;353(23):2462-76.

83. Sandborn WJ, Colombel JF, Panés J, Castillo M, Robinson AM, Zhou Q, Yang M, Thakkar R. Exploring the use of adalimumab for patients with moderate Crohn's disease: subanalyses from induction and maintenance trials. J Crohns Colitis. 2013;7(12):958-67.

84. Schreiber S, Khaliq-Kareemi M, Lawrance IC, Thomsen O, Hanauer SB, McColm J, Bloomfield R, Sandborn WJ, Investigators PS. Maintenance therapy with certolizumab pegol for Crohn's disease. N Engl J Med. 2007;357(3):239-50.

85. Sepah YJ, Sadiq MA, Chu DS, Dacey M, Gallemore R, Dayani P, Hanout M, Hassan M, Afridi R, Agarwal A, Halim MS, Do DV, Nguyen QD. Primary (Month-6) Outcomes of the STOP-Uveitis Study: Evaluating the Safety, Tolerability, and Efficacy of Tocilizumab in Patients With Noninfectious Uveitis. Am J Ophthalmol. 2017;183:173-80.
86. Shalaby U. Diltiazem co treatment with cyclosporine for induction of disease remission in sight-threatening non-infectious intraocular inflammation. Jpn J Ophthalmol. 2017;61(2):169-78.

87. Smolen JS, Beaulieu A, Rubbert-Roth A, Ramos-Remus C, Rovensky J, Alecock E, Woodworth T, Alten $\mathrm{R}$, Investigators O. Effect of interleukin-6 receptor inhibition with tocilizumab in patients with rheumatoid arthritis (OPTION study): a double-blind, placebo-controlled, randomised trial. Lancet. 2008;371(9617):987-97.

88. Sugita S, Kawazoe Y, Imai A, Yamada Y, Horie S, Mochizuki M. Inhibition of Th17 differentiation by anti-TNF-alpha therapy in uveitis patients with Behcet's disease. Arthritis Res Ther. 2012;14(3):R99.

89. Suhler EB, Smith JR, Wertheim MS, Lauer AK, Kurz DE, Pickard TD, Rosenbaum JT. A prospective trial of infliximab therapy for refractory uveitis: preliminary safety and efficacy outcomes. Arch Ophthalmol. 2005;123(7):903-12.

90. Suhler EB, Smith JR, Giles TR, Lauer AK, Wertheim MS, Kurz DE, Kurz PA, Lim L, Mackensen F, Pickard TD, Rosenbaum JT. Infliximab therapy for refractory uveitis: 2-year results of a prospective trial. Arch Ophthalmol. 2009;127(6):819-22.

91. Suhler E, Jaffe G, Nguyen QD, Brezin A, Zierhut M, Vitale A, Velthoven MV, Adan A, Lim L, Kramer M, Schlaen A, Fortin E, Muccioli C, Goto H, Kaburaki T, Camez A, Song A, Kron M, Tari S, Dick A (2016) Long-Term safety and efficacy of adalimumab in patients with non-infectious intermediate, posterior, or panuveitis in an ongoing open-label study (Abstract only). https://acrabstracts.org/. Accessed 11 June 2017.

92. Suttorp-Schulten MS, Rothova A. The possible impact of uveitis in blindness: a literature survey. Br J Ophthalmol. 1996;80(9):844-8.

93. Tesmer LA, Lundy SK, Sarkar S, Fox DA. Th17 cells in human disease. Immunol Rev. 2008;223:87-113.

94. Tran VT, Auer C, Guex-Crosier Y, Pittet N, Herbort CP. Epidemiological characteristics of uveitis in Switzerland. Int Ophthalmol. 1994;18(5):293-8.

95. Tsambaos D, Eichelberg D, Goos M. Behçet's syndrome: treatment with recombinant leukocyte alpha-interferon. Arch Dermatol Res. 1986;278(4):335-6.

96. Veroux M, Tallarita T, Corona D, D'Assoro A, Gurrieri C, Veroux P. Sirolimus in solid organ transplantation: current therapies and new frontiers. Immunotherapy. 2011;3(12):1487-97. 
97. Verstovsek S, Mesa RA, Gotlib J, Levy RS, Gupta V, DiPersio JF, Catalano JV, Deininger M, Miller C, Silver RT, Talpaz M, Winton EF, Harvey JH, Arcasoy MO, Hexner E, Lyons RM, Paquette R, Raza A, Vaddi K, Erickson-Viitanen S, Koumenis IL, Sun W, Sandor V, Kantarjian HM. A double-blind, placebo-controlled trial of ruxolitinib for myelofibrosis. N Engl J Med. 2012;366(9):799-807.

98. Whitcup SM, Salvo EC, Nussenblatt RB. Combined cyclosporine and corticosteroid therapy for sight-threatening uveitis in Behçet's disease. Am J Ophthalmol. 1994;118(1):39-45.

99. Xu H, Chen M. Targeting the complement system for the management of retinal inflammatory and degenerative diseases. Eur J Pharmacol. 2016;787:94-104.

100. Yokota S, Imagawa T, Mori M, Miyamae T, Aihara Y, Takei S, Iwata N, Umebayashi H, Murata T, Miyoshi M,
Tomiita M, Nishimoto N, Kishimoto T. Efficacy and safety of tocilizumab in patients with systemic-onset juvenile idiopathic arthritis: a randomised, double-blind, placebo-controlled, withdrawal phase III trial. Lancet. 2008;371(9617):998-1006.

101. Yoshimura T, Sonoda KH, Ohguro N, Ohsugi Y, Ishibashi T, Cua DJ, Kobayashi $\mathrm{T}$, Yoshida $\mathrm{H}$, Yoshimura A. Involvement of Th17 cells and the effect of anti-IL-6 therapy in autoimmune uveitis. Rheumatology (Oxford). 2009;48(4):347-54.

102. Zulian F, Balzarin M, Falcini F, Martini G, Alessio M, Cimaz R, Cimino L, Zannin ME. Abatacept for severe anti-tumor necrosis factor alpha refractory juvenile idiopathic arthritis-related uveitis. Arthritis Care Res (Hoboken). 2010;62(6):821-5. 